\title{
The influence of hydrothermal brine on the short-term strength and elastic modulus of sandstones from exploration well EPS-1 at Soultz-sous-Forêts (France)
}

\author{
Michael J. Heap* ${ }^{*}$, Thierry Reuschlé, Alexandra R. L. Kushnir and Patrick Baud
}

\section{*Correspondence:}

heap@unistra.fr

Géophysique Expérimentale,

Institut de Physique de

Globe de Strasbourg (UMR

7516 CNRS, Université de

Strasbourg/EOST), 5 rue René

Descartes, 67084 Strasbourg

Cedex, France

\begin{abstract}
Laboratory studies designed to provide the strength of rocks are typically performed on either dry- or water-saturated rock samples. To better understand the mechanical behaviour of rocks in a geothermal context, we provide here the short-term strength and static elastic modulus of sandstones from exploration well EPS-1 at the Soultz-sous-Forêts geothermal site (France) saturated in hydrothermal brine sourced from the adjacent production well GPK-2. We performed 59 uniaxial compressive strength experiments on samples of Buntsandstein sandstones sampled from six depths $(1008,1022,1069,1107,1290$, and 1414 m). Samples were deformed oven-dry (i.e., unsaturated), water-saturated (deionised water), or brine-saturated. Relative to the dry state, strength was reduced by between 24 and 39\% and elastic modulus was reduced by between 9 and 19\% when the samples were saturated with water. However, we observed no measurable difference in strength and elastic modulus between samples saturated in water and brine. These reductions in strength and elastic modulus in the presence of water or brine are considered the result of a reduction in specific surface-free energy. Changes to short-term strength and elastic modulus in the presence of hydrothermal brines likely require brines with higher salinities and/or lower values of $\mathrm{pH}$ than those typically found within the Upper Rhine Graben (the brine from GPK-2 has a salinity of $10 \%$ and a pH of 5.5). These new data can be used to assist reservoir prospection, stimulation, and optimisation strategies at the geothermal sites within the Upper Rhine Graben.
\end{abstract}

Keywords: Buntsandstein, Uniaxial compressive strength, Brine, Hydrothermal fluid, Geothermal reservoir

\section{Introduction}

Experimental studies designed to understand the mechanical behaviour and failure modes of sandstones are often performed either dry or using deionised or distilled water as the pore fluid (e.g., Menéndez et al. 1996; Wong et al. 1997; Baud et al. 2000; Klein et al. 2001; Bésuelle et al. 2003; Baud et al. 2004; Fortin et al. 2005; Heap et al. 2009a). However, the results of these studies may not be directly applicable to the study of geothermal resources, where the rocks in situ are saturated with hydrothermal brines that

(c) The Author(s) 2018. This article is distributed under the terms of the Creative Commons Attribution 4.0 International License (http://creativecommons.org/licenses/by/4.0/), which permits unrestricted use, distribution, and reproduction in any medium, provided you give appropriate credit to the original author(s) and the source, provide a link to the Creative Commons license, and indicate if changes were made. 
are typically high salinity, low $\mathrm{pH}$, and contain a rich assortment of dissolved elements (e.g., Aquilina et al. 1997; Sanjuan et al. 2010, 2016).

Pore fluid salinity has been shown previously to influence the strength of sandstones. For example, Shukla et al. (2013) found, using an axial strain rate of $5 \times 10^{-5} \mathrm{~s}^{-1}$, that the uniaxial compressive strength of two sandstones (both sourced from a quarry in southeast Melbourne, Australia) decreased (by 7.5 and 27\%, respectively) up to a salinity of $5 \%$ $\mathrm{NaCl}$, but increased (by 6.3 and $2.5 \%$, respectively) as salinity was increased up to $15 \%$ $\mathrm{NaCl}$. The observed decrease and increase in strength was interpreted by these authors as a result of (1) mineralogical interactions between salts and rock minerals and (2) salt crystallisation, respectively. Rathnaweera et al. (2014) found, using an axial strain rate of $2 \times 10^{-5} \mathrm{~s}^{-1}$, that the uniaxial compressive strength of Gosford sandstone (New South Wales, Australia) decreased (by $8.8 \%$ ) as salinity was increased to $10 \% \mathrm{NaCl}$ and then increased (by $9.7 \%$ ) when salinity was increased to $30 \% \mathrm{NaCl}$. Triaxial experiments at confining pressures up to $60 \mathrm{MPa}$ showed that the compressive strength of sandstone increased as salinity was increased from 0 to $30 \% \mathrm{NaCl}$ (Rathnaweera et al. 2015; Huang et al. 2018). However, Feucht and Logan (1990) found that the strength of sandstones saturated with low ionic strength solutions $\left(\mathrm{NaCl}, \mathrm{CaCl}_{2}\right.$, and $\left.\mathrm{Na}_{2} \mathrm{SO}_{4}\right)$ did not change with respect to the water-saturated case, but that intermediate ionic strengths $(1.0 \mathrm{M})$ increased the strength of the sandstone (by up to $20 \%$ ) and high ionic strengths $(5.0 \mathrm{M})$ decreased strength (by up to 20\%). Nara et al. (2014) found that the velocity of a crack growing subcritically decreased and did not change, respectively, as salinity $(\mathrm{NaCl})$ was increased up to $1.0 \mathrm{~mol} / \mathrm{l}$ for Berea (clay-poor) and Shirahama sandstone (clay-rich). These authors considered that the presence of clays in the Shirahama sandstone influenced subcritical crack growth by changing the width of the electric double layer. The influence of $\mathrm{pH}$ on the strength of sandstones has received much less attention than the influence of pore fluid salinity. Singh et al. (1999), for example, measured a reduction in the uniaxial compressive strength of sandstone from $\sim 65$ to $\sim 40 \mathrm{MPa}$ as the $\mathrm{pH}$ was reduced from 7 to 2 . Wang et al. (2015) also found that low-pH pore fluids reduced the strength of sandstone deformed in triaxial compression. However, Feucht and Logan (1990) found that strength changes due to $\mathrm{pH}$ were only apparent for sandstone samples saturated with solutions of intermediate ionic $\left(\mathrm{NaCl}, \mathrm{CaCl}_{2}\right.$, and $\left.\mathrm{Na}_{2} \mathrm{SO}_{4}\right)$ strength. Double-torsion experiments have shown that subcritical crack growth rates increase as the hydroxyl $\left(\mathrm{OH}^{-}\right)$concentration is increased (Atkinson and Meredith 1981).

A recent study by Heap et al. (2019) provided strength data for samples of Buntsandstein sandstone from exploration well EPS-1 at the geothermal site at Soultz-sousForêts, France (Fig. 1). The uniaxial compressive strength of the tested Buntsandstein samples, when oven-dry, ranged from $\sim 50 \mathrm{MPa}$ (for high-porosity samples; porosity $\sim 0.25$ ) up to $\sim 250 \mathrm{MPa}$ (for low-porosity samples; porosity $\sim 0.04$ ). These authors additionally showed that the ratio of water-saturated-to-dry strength of the tested Buntsandstein samples varied from $\sim 0.55$ to $\sim 0.84$, indicating that these sandstones are much weaker when saturated with water, in accordance with most other experimental studies on sandstones (e.g., Hawkins and McConnell 1992; Baud et al. 2000). However, Heap et al. (2019) only deformed samples saturated with deionised water. In this contribution, we extend the study of Heap et al. (2019) by performing uniaxial compressive strength experiments on Buntsandstein samples taken from EPS-1 saturated with the in situ 


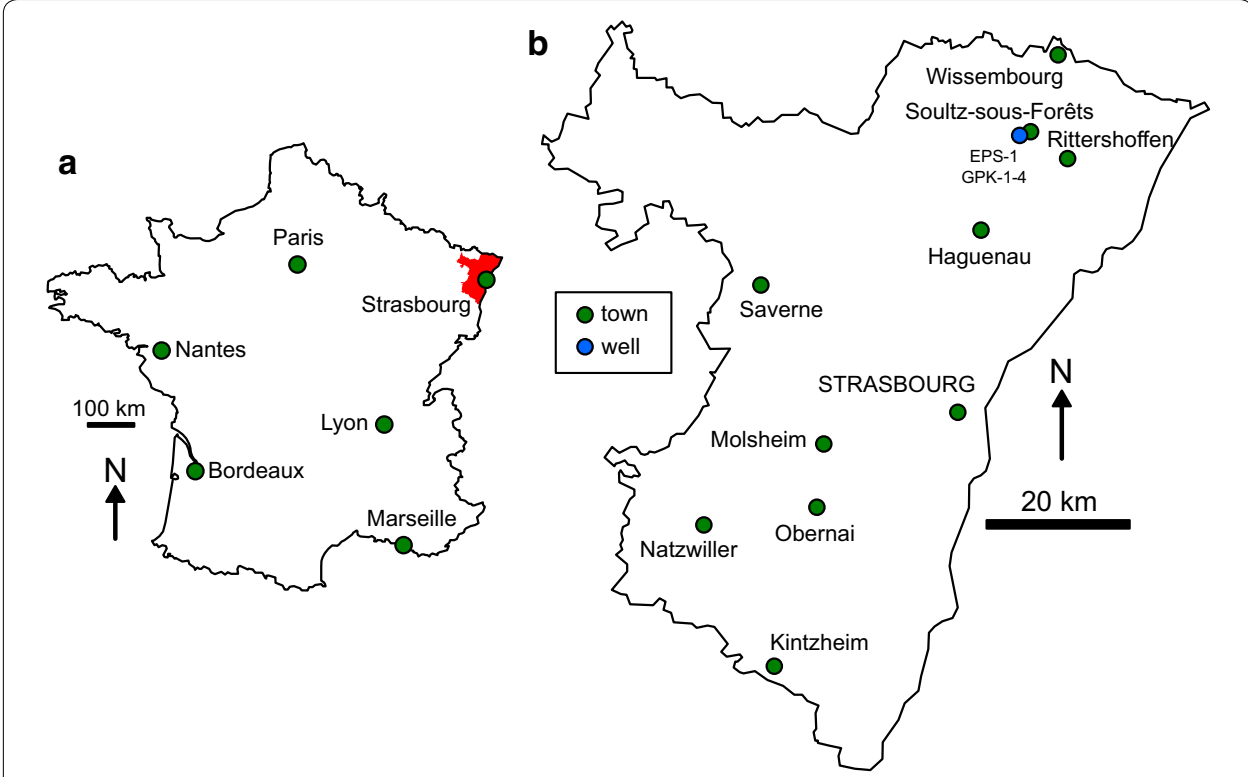

Fig. 1 a Map of France showing the location of the Bas-Rhin department of Alsace (in red). b Map of the Bas-Rhin department of Alsace (shown in red in a) showing the location of the major cities/towns in Alsace, including Soultz-sous-Forêts and Rittershoffen (green circles), and the wells EPS-1 and GPK-1-4 at Soultz-sous-Forêts (blue circles)

hydrothermal fluid (taken from production well GPK-2). These data can be used to help guide and optimise current geothermal sites in the Upper Rhine Graben and those currently in development (e.g., at Illkirch and Vendenheim, both in Alsace, France), that increasingly target the interface between the granitic basement and the overlying Permian and Triassic sedimentary rocks. For example, the Buntsandstein was stimulated at the Rittershoffen geothermal site (France; Fig. 1b) in 2013 (Vidal et al. 2016; Baujard et al. 2017). If certain lithologies are notably weaker or stronger when saturated with the in situ brine, such data could be used to help guide future stimulation strategies.

\section{Case study: Soultz-sous-Forêts (France)}

Soultz-sous-Forêts (e.g., Kappelmeyer et al. 1991; Baria et al. 1999; Gérard et al. 2006; Fig. 1) is one of many geothermal power plants located in the Upper Rhine Graben (Vidal and Genter, 2018), a 350-km-long and 50-km-wide Cenozoic rift valley that extends from Frankfurt (Germany) to Basel (Switzerland). Geothermal energy exploitation is prevalent in this area due to the presence of anomalously high thermal gradients (areas of geothermal interest typically have thermal gradients $>80^{\circ} \mathrm{C}$ ) attributed to hydrothermal convection (e.g., Ledésert et al. 1996; Pribnow and Schellschmidt 2000; Buchmann and Connolly 2007; Guillou-Frottier et al. 2013; Baillieux et al. 2013; Magnenet et al. 2014). The hydrothermal fluids at Soultz-sous-Forêts are high-salinity (total dissolved solids (TDS) is typically $100 \mathrm{~g} / \mathrm{l}$ ) (Aquilina et al. 1997; Sanjuan et al. 2010; Scheiber et al. 2012). The main electrolytes are $\mathrm{Na}^{+}, \mathrm{K}^{+}, \mathrm{Ca}^{2+}, \mathrm{Cl}^{-}$, and $\mathrm{CO}_{4}{ }^{2-}$ and there are trace amounts of transition and post-transition metals, alkali metals, and alkaline Earth metals (in the $\mu$ g to mg range) (Aquilina et al. 1997; Sanjuan et al. 2010; Scheiber et al. 2012). The pH of the hydrothermal fluid at Soultz-sous-Forêts is typically between 
5.0 and 6.0 and remains roughly constant from the wellhead down to a depth of about 3500 m (Aquilina et al. 1997; Sanjuan et al. 2010; Scheiber et al. 2012).

The geology at Soultz-sous-Forêts consists of a fractured Palaeozoic granitic basement (e.g., Ledésert et al. 1993; Genter and Traineau 1996; Genter et al. 1997; Hooijkaas et al. 2006; Sausse et al. 2006; Dezayes et al. 2010; Genter et al. 2010; Villeneuve et al. 2018; Glaas et al. 2018) and an overlying sequence of Permian and Triassic sedimentary rocks (Haffen et al. 2013; Vidal et al. 2015; Griffiths et al. 2016; Aichholzer et al. 2016; Heap et al. 2017; Kushnir et al. 2018a, b; Heap et al. 2019). These rocks show evidence of alteration as a result of the circulating hydrothermal fluids (e.g., Ledésert et al. 1999; Sausse 2002; Sausse et al. 2006; Bartier et al. 2008; Ledésert et al. 2010; Fritz et al. 2010). Exploration well EPS-1 provides full core (to a diameter of $78 \mathrm{~mm}$ between a depth of 930-1996 m and to a diameter of $57 \mathrm{~mm}$ from 1997 to $2227 \mathrm{~m}$ ) of the lowermost part of the Muschelkalk unit (from 930 to $1007 \mathrm{~m}$ ), the entire Buntsandstein unit (from 1008 to $1417 \mathrm{~m}$ ), and about $800 \mathrm{~m}$ of the fractured Palaeozoic granitic basement. Due to the availability of core material, Soultz-sous-Forêts represents an ideal case study for investigating the physical and mechanical properties of the Buntsandstein, a unit known to be laterally extensive in the Upper Rhine Graben (Aichholzer et al. 2016; Vidal and Genter 2018).

\section{Materials and methods}

The study of Heap et al. (2019) sampled the Buntsandstein lithostratigraphic unit (a stratigraphic column is provided in Fig. 2) at regular $(\sim 40-50 \mathrm{~m})$ depth intervals (between 1008 and $1414 \mathrm{~m}$ ) from the EPS-1 exploration well at the Soultz-sous-Forêts geothermal site. These authors provided values of "dry" (dried at $40{ }^{\circ} \mathrm{C}$ in a vacuum oven for at least $48 \mathrm{~h}$ prior to deformation) and "water-saturated" or "wet" (vacuum-saturated in deionised water and deformed in a water bath) uniaxial compressive strength for sandstones sampled from twelve depths. We test here the influence of saturation with hydrothermal fluid (vacuum-saturated in hydrothermal fluid and deformed in a bath of hydrothermal fluid) on a subset of these samples (six of the 12) chosen to represent the measured variability in grain size, porosity, and clay content (one sandstone from the Voltzia unit, one from the Couches Intermédiaires unit, two from the Karlstal unit, one from the Trifels unit, and one from the Anté-Annweiler unit; Fig. 2). The six samples collected from exploration well EPS-1 are feldspathic ( $>10 \mathrm{wt} \%$ feldspar) or quartz-rich $(<10 \mathrm{wt} \%$ feldspar) sandstones that contain variable amounts of clay (muscovite/illitesmectite) (from 2 to $13.1 \mathrm{wt} \%$ ) (Table 1; Heap et al. 2017). The average porosity and grain diameter of these samples vary from 0.076 and 0.144 and from 142 to $424 \mu \mathrm{m}$, respectively (Table 2; Heap et al. 2017). The textural and microstructural features of these sandstones are summarised in Table 2 (see Heap et al. (2017) for further details) and back-scattered scanning electron microscope images, showing their microstructural and microtextural properties, are provided in Fig. 3.

Nine-to-eleven cylindrical samples, $20 \mathrm{~mm}$ in diameter, were cored from the $6 \mathrm{~m}$-long, $78 \mathrm{~mm}$-diameter cores retrieved from the EPS-1 core repository at Merkwiller-Pechelbronn (Alsace, France) and precision ground to a nominal length of $40 \mathrm{~mm}$. Photographs showing examples of the prepared samples are provided in Fig. 2. The samples were cored so that their axes were parallel to the EPS-1 borehole (i.e., perpendicular to 


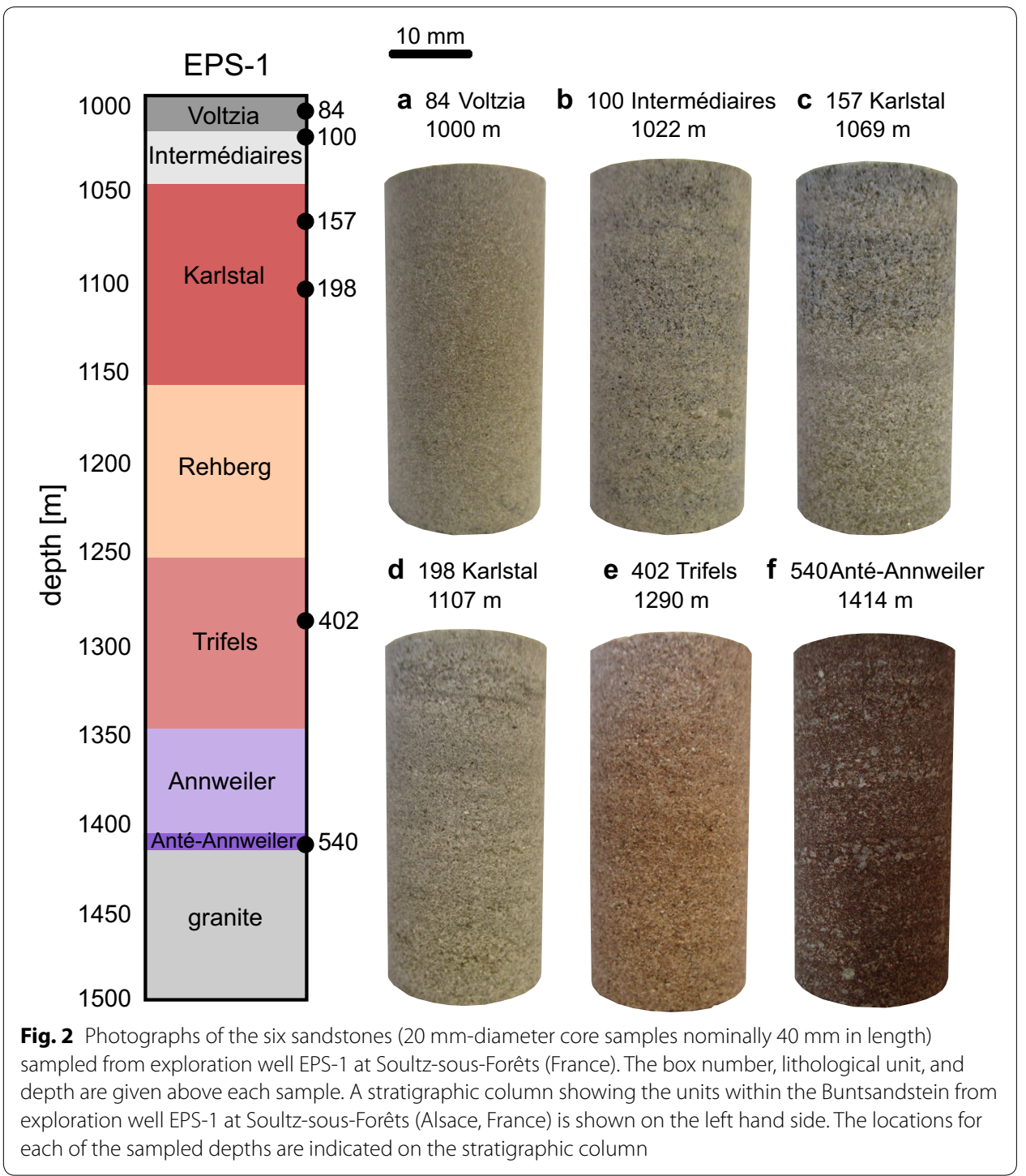

bedding). Once prepared, all of the samples were washed using tapwater (to remove any water-soluble grinding fluid) and then dried in a vacuum oven at $40{ }^{\circ} \mathrm{C}$ for at least $48 \mathrm{~h}$. The connected porosity of each sample was determined using the connected (skeletal) volume measured by a helium pycnometer (Micromeritics AccuPyc II 1340) and the bulk volume calculated using the sample dimensions.

The prepared cylindrical samples were deformed uniaxially at a strain rate of $1.0 \times 10^{-5}$ $\mathrm{s}^{-1}$ until macroscopic failure (the formation of a sample-lengthscale fracture). A third of the samples were deformed dry (dried at $40{ }^{\circ} \mathrm{C}$ in a vacuum oven for at least $48 \mathrm{~h}$ prior to deformation), a third wet (vacuum-saturated in deionised water and deformed in a water bath), and a third saturated with hydrothermal fluid (vacuum-saturated in hydrothermal fluid and deformed in a bath of hydrothermal fluid) (see Fig. 4 for a schematic diagram and a photograph of the experimental device). The saturation procedure consisted of two steps. First, the vacuum-dried samples were placed inside a bell jar that was then vacuumed for at least $12 \mathrm{~h}$. Second, degassed (using a Venturi siphon with municipal 


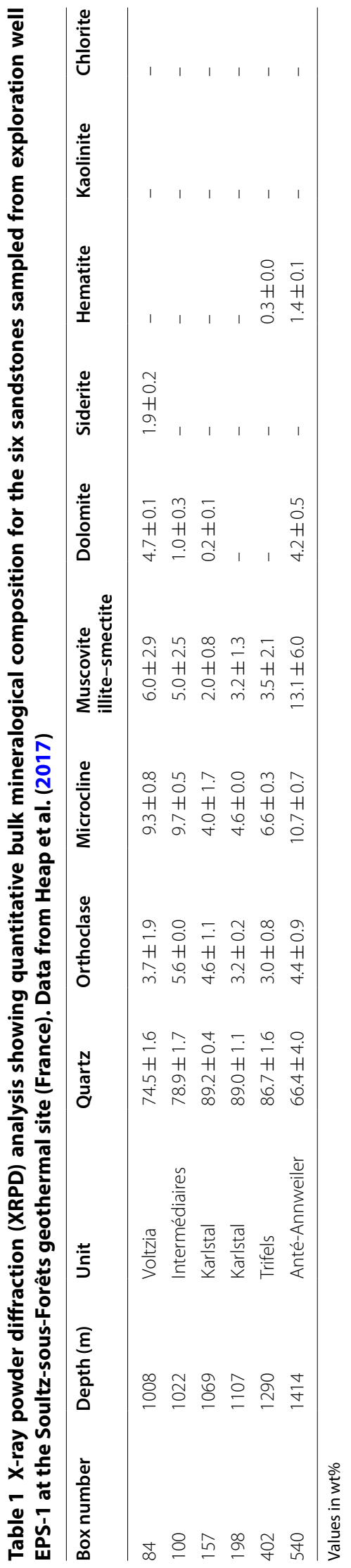


Table 2 Average connected porosity, average grain diameter, specific surface area, average dry P-wave velocity, and average gas permeability for each of the six sandstones sampled from exploration well EPS-1 at the Soultz-sous-Forêts geothermal site (France)

\begin{tabular}{|c|c|c|c|c|c|c|c|}
\hline $\begin{array}{l}\text { Box } \\
\text { number }\end{array}$ & Depth (m) & Unit & $\begin{array}{l}\text { Average } \\
\text { connected } \\
\text { porosity }\end{array}$ & $\begin{array}{l}\text { Average } \\
\text { grain } \\
\text { diameter } \\
(\mu \mathrm{m})\end{array}$ & $\begin{array}{l}\text { Specific } \\
\text { surface } \\
\text { area }\left(\mathrm{m}^{2} /\right. \\
\mathrm{kg})\end{array}$ & $\begin{array}{l}\text { Average } \\
\text { dry P-wave } \\
\text { velocity } \\
(\mathrm{km} / \mathrm{s})\end{array}$ & $\begin{array}{l}\text { Average gas } \\
\text { permeability } \\
\left(\mathrm{m}^{2}\right)\end{array}$ \\
\hline 84 & 1008 & Voltzia & 0.096 & 142 & 1442 & 3.7 & $2.82 \times 10^{-18}$ \\
\hline 100 & 1022 & $\begin{array}{l}\text { Intermédi- } \\
\text { aires }\end{array}$ & 0.065 & 306 & 665 & 3.6 & $6.45 \times 10^{-18}$ \\
\hline 157 & 1069 & Karlstal & 0.117 & 424 & 204 & 3.4 & $1.33 \times 10^{-16}$ \\
\hline 198 & 1107 & Karlstal & 0.097 & 192 & 1485 & 3.2 & $7.95 \times 10^{-17}$ \\
\hline 402 & 1290 & Trifels & 0.131 & 259 & 1349 & 3.1 & $2.37 \times 10^{-16}$ \\
\hline 540 & 1414 & $\begin{array}{l}\text { Anté-Ann- } \\
\text { weiler }\end{array}$ & 0.075 & 379 & 6170 & 2.9 & $7.89 \times 10^{-18}$ \\
\hline
\end{tabular}

Physical property data taken from Heap et al. (2017). Elastic wave velocities and porosities were measured at room pressure and permeabilities were measured under a confining pressure of $1 \mathrm{MPa}$ (see Heap et al. (2017) for details)

water as the motive fluid) deionised water or hydrothermal fluid was introduced into the bell jar whilst under vacuum. This procedure ensured that the samples were completely saturated. The hydrothermal fluid was taken from production well GPK-2 at the Soultz-sous-Forêts geothermal site; the composition of the fluid is provided in Table 3. The hydrothermal fluid, sampled in 2011, is high-salinity (TDS of $97 \mathrm{~g} / \mathrm{l}$ ) and has a pH of 5.5 (Table 3). Once saturated, the brine-saturated samples were left in a beaker of brine for 7 days prior to deformation. For the oven-dry samples, a lubricating wax was applied to the end-faces of the samples prior to deformation to avoid problems associated with the friction between the sample and the pistons. During deformation, axial displacement and axial load were measured using a linear variable differential transducer (LVDT) and a load cell, respectively. These measurements were converted to axial strain and axial stress using the sample dimensions. The static elastic modulus of each sample was determined from the elastic portion of the stress-strain curves. We adopt the convention that compressive stresses and strains are positive.

\section{Results}

Representative uniaxial stress-strain curves for the dry Buntsandstein samples are provided in Fig. 5a (data available in Table 4). The average dry strength of the six Buntsandstein sandstone samples tested varied from $\sim 65$ to $\sim 150 \mathrm{MPa}$ (Fig. 5a). Representative uniaxial stress-strain curves for dry, water-saturated, and brine-saturated samples (samples from core box number 84) are shown in Fig. 5b. These curves show that the uniaxial compressive strength is lower when the sample is saturated with water or brine. In the example shown in Fig. 5b, the dry strength is $146.0 \mathrm{MPa}$ and the water- and brine-saturated strengths are 94.2 and $94.1 \mathrm{MPa}$, respectively (Table 4). The stress-strain curves and uniaxial compressive strengths of the water- and brine-saturated samples are very similar (Fig. 5b; Table 4). The representative curves shown in Fig. 5b also show that the axial strain at macroscopic failure and the slope of the stress-strain curve in the elastic region (i.e., the static elastic modulus) are lower when the sample is saturated with water or brine (Table 4). 


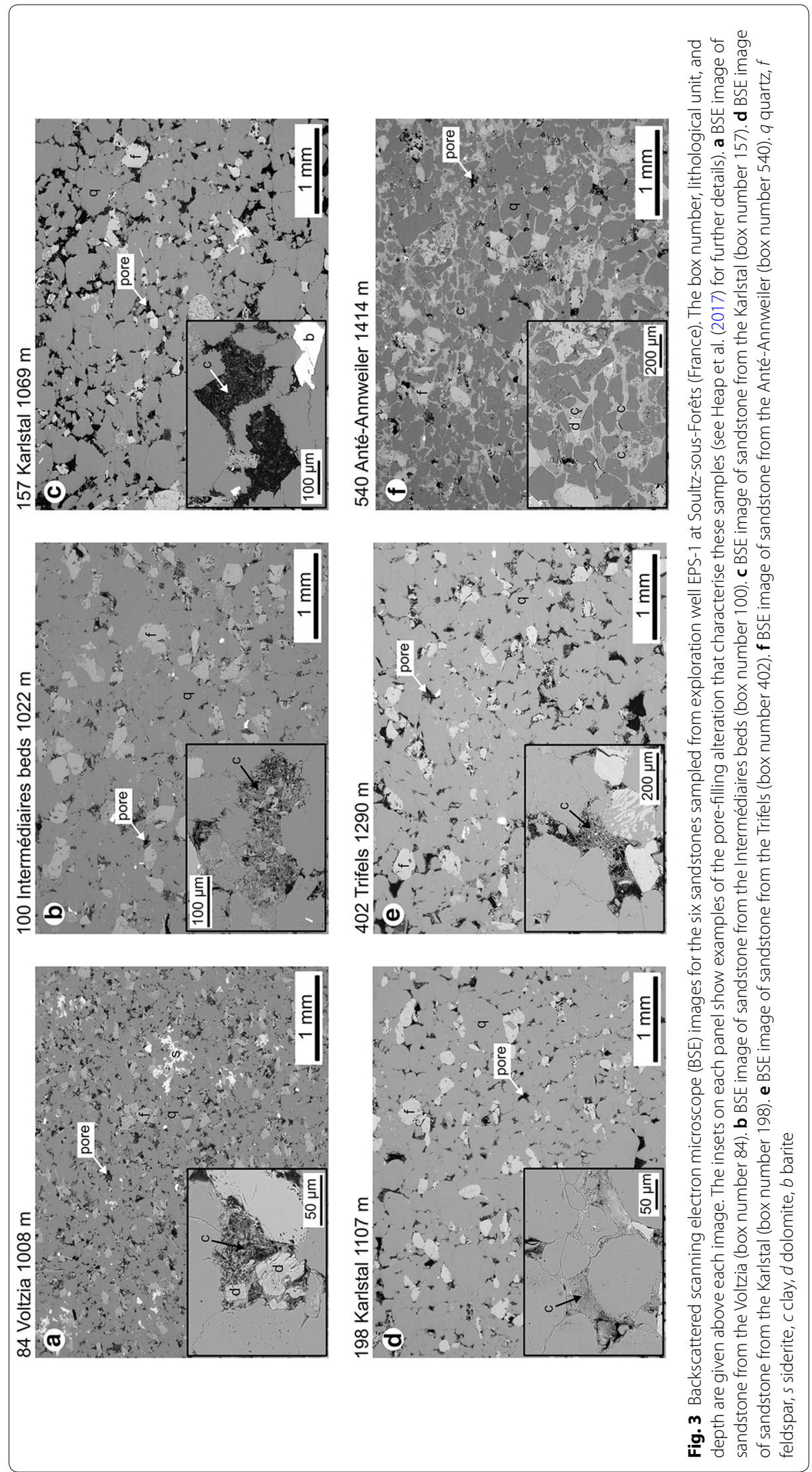



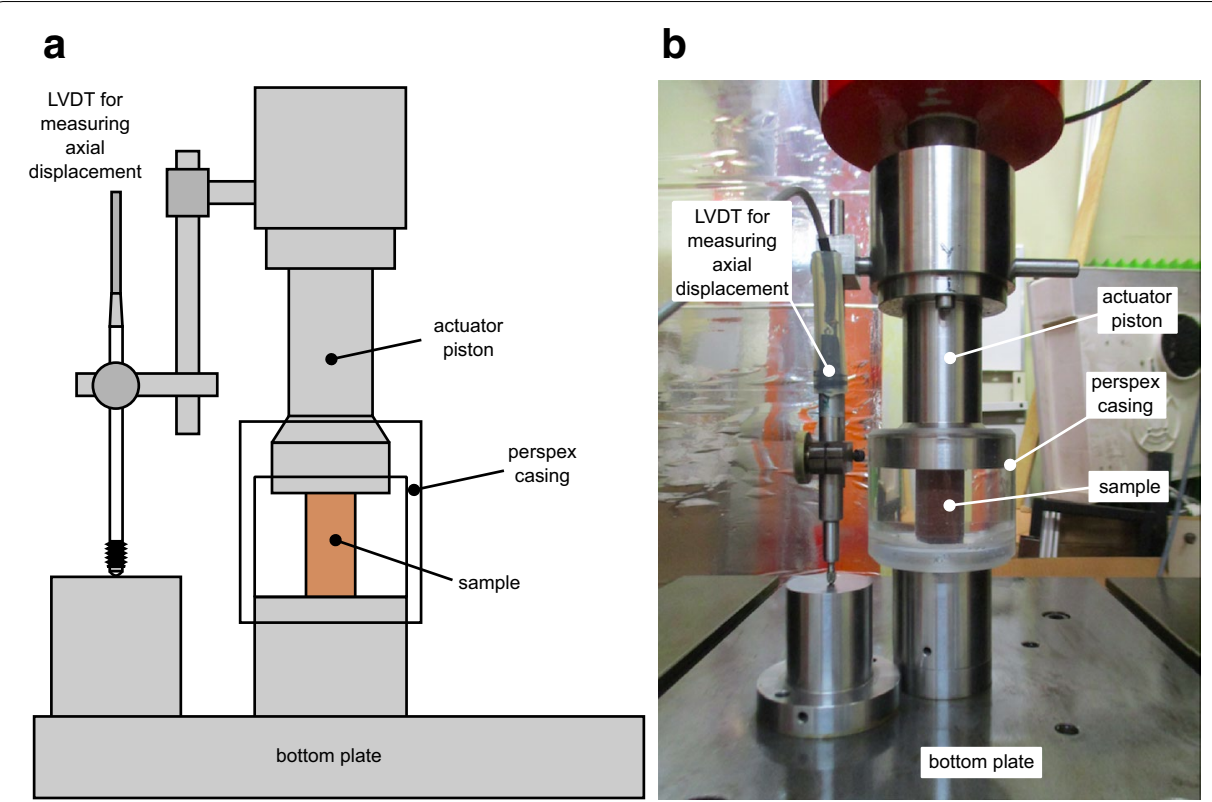

Fig. 4 a Schematic diagram showing the uniaxial compression apparatus used in the study (modified from Heap et al. 2014). b Photograph of the uniaxial compression apparatus used in the study (showing a sample of 540 deformed under water-saturated conditions). For the water- and brine-saturated experiments, the perspex casing is filled with deionised water and hydrothermal brine, respectively

Dry (white circles), water-saturated (black circles), and brine-saturated (grey circles) uniaxial compressive strengths and elastic moduli are plotted as a function of connected porosity in Fig. 6a and Fig. 6b, respectively (data available in Table 4). For the rocks tested, there is no obvious relationship between strength (Fig. 6a) or elastic modulus (Fig. 6b) and the connected porosity. The average values of dry, water-saturated, and brine-saturated uniaxial compressive strengths and elastic moduli are provided in Table 5. These data also show that the average water-saturated and brine-saturated strength and elastic modulus are systematically lower than the dry strength and elastic modulus for all of the studied sandstones (Table 5). However, the difference in strength and elastic modulus does not vary systematically between the water-saturated and brinesaturated samples (Table 5). For example, the brine-saturated strength is slightly higher than the water-saturated strength for samples 84, 157, 198, and 402 and slightly lower for samples 100 and 540 (Table 5). The brine-saturated elastic modulus is slightly higher than the water-saturated elastic modulus for samples 84, 157, 198, and 402 and slightly lower for samples 100 and 540 (Table 5). Differences in strength and elastic modulus between the water- and brine-saturated samples are much smaller than the differences between the dry and water- and brine-saturated samples (Table 5).

The ratios of water-saturated-to-dry strength (white circles), brine-saturated-to-dry strength (black circles), and water-saturated-to-brine-saturated strength (grey circles) are plotted as a function of connected porosity and clay content in Fig. 7a and Fig. 7b, respectively (data available in Table 6). The ratio of water-saturated-to-dry strength varies from 0.62 and 0.76 , and the ratio of brine-saturated-to-dry strength varies from 0.61 to 0.87 (Table 6). The ratio of water-saturated-to-brine-saturated strength varies from 0.83 to 1.13 (Table 6). However, although the ratio of water-saturated-to-brine-saturated 
Table 3 Composition and properties of the hydrothermal fluid sampled from production well GPK-2 at Soultz-sous-Forêts (France) in 2011. Data from Scheiber et al. (2012)

\begin{tabular}{|c|c|}
\hline & Quantity \\
\hline $\mathrm{pH}$ & 5.5 \\
\hline Total dissolved solids (g/l) & 97 \\
\hline $\mathrm{Na}(\mathrm{mg} / \mathrm{l})$ & 26,677 \\
\hline $\mathrm{K}(\mathrm{mg} / \mathrm{l})$ & 3220 \\
\hline $\mathrm{Ca}(\mathrm{mg} / \mathrm{l})$ & 6880 \\
\hline $\mathrm{Mg}(\mathrm{mg} / \mathrm{l})$ & 124 \\
\hline $\mathrm{Cl}(\mathrm{mg} / \mathrm{l})$ & 58,271 \\
\hline $\mathrm{SO}_{4}(\mathrm{mg} / \mathrm{l})$ & 177 \\
\hline $\mathrm{SiO}_{2}(\mathrm{mg} / \mathrm{l})$ & 226 \\
\hline $\mathrm{Sr}(\mathrm{mg} / \mathrm{l})$ & 397 \\
\hline Li (mg/l) & 152 \\
\hline $\operatorname{Br}(m g / l)$ & 264 \\
\hline $\mathrm{NO}_{3}(\mathrm{mg} / \mathrm{l})$ & $<0.5$ \\
\hline $\mathrm{F}(\mathrm{mg} / \mathrm{l})$ & 1.9 \\
\hline $\mathrm{PO}_{4}(\mathrm{mg} / \mathrm{l})$ & 1.4 \\
\hline$B(\mathrm{mg} / \mathrm{l})$ & 34.7 \\
\hline $\mathrm{NH}_{4}(\mathrm{mg} / \mathrm{l})$ & 21.4 \\
\hline $\mathrm{Fe}(\mathrm{mg} / \mathrm{l})$ & 27.6 \\
\hline $\mathrm{Mn}(\mathrm{mg} / \mathrm{l})$ & 14.8 \\
\hline $\mathrm{Ba}(\mathrm{mg} / \mathrm{l})$ & 19.4 \\
\hline As (mg/l) & 8.3 \\
\hline $\mathrm{Rb}(\mathrm{mg} / \mathrm{l})$ & 23.5 \\
\hline $\mathrm{Cs}(\mathrm{mg} / \mathrm{l})$ & 14.6 \\
\hline $\mathrm{Ge}(\mu \mathrm{g} / \mathrm{l})$ & 50.2 \\
\hline $\mathrm{Al}(\mu \mathrm{g} / \mathrm{l})$ & 42 \\
\hline Zn $(\mu g / l)$ & 2163 \\
\hline $\mathrm{Pb}(\mu \mathrm{g} / \mathrm{l})$ & 254 \\
\hline $\mathrm{Cd}(\mu \mathrm{g} / \mathrm{l})$ & 5.8 \\
\hline $\mathrm{Co}(\mu \mathrm{g} / \mathrm{l})$ & 2.0 \\
\hline $\operatorname{Cr}(\mu \mathrm{g} / \mathrm{l})$ & 1.0 \\
\hline $\mathrm{Cu}(\mu \mathrm{g} / \mathrm{l})$ & 3.7 \\
\hline $\mathrm{Ni}(\mu \mathrm{g} / \mathrm{l})$ & 1.9 \\
\hline $\mathrm{Ag}(\mu \mathrm{g} / \mathrm{l})$ & 1.1 \\
\hline
\end{tabular}

strength fluctuates above and below unity, there is no systematic variation with connected porosity (Fig. 7a) or clay content (Fig. 7b). The ratios of water-saturated-to-dry elastic modulus (white circles), brine-saturated-to-dry elastic modulus (black circles), and water-saturated-to-brine-saturated elastic modulus (grey circles) are plotted as a function of connected porosity and clay content in Fig. 8a and Fig. 8b, respectively (data available in Table 6). The ratio of water-saturated-to-dry elastic modulus varies from 0.81 and 0.91 , and the ratio of brine-saturated-to-dry strength varies from 0.81 to 0.96 (Table 6). The ratio of water-saturated-to-brine-saturated strength varies from 0.87 to 1.03 (Table 6). Similar to the strength data, although the ratio of water-saturated-tobrine-saturated strength fluctuates above and below unity, there is no systematic variation with connected porosity (Fig. 8a) or clay content (Fig. 8b). 

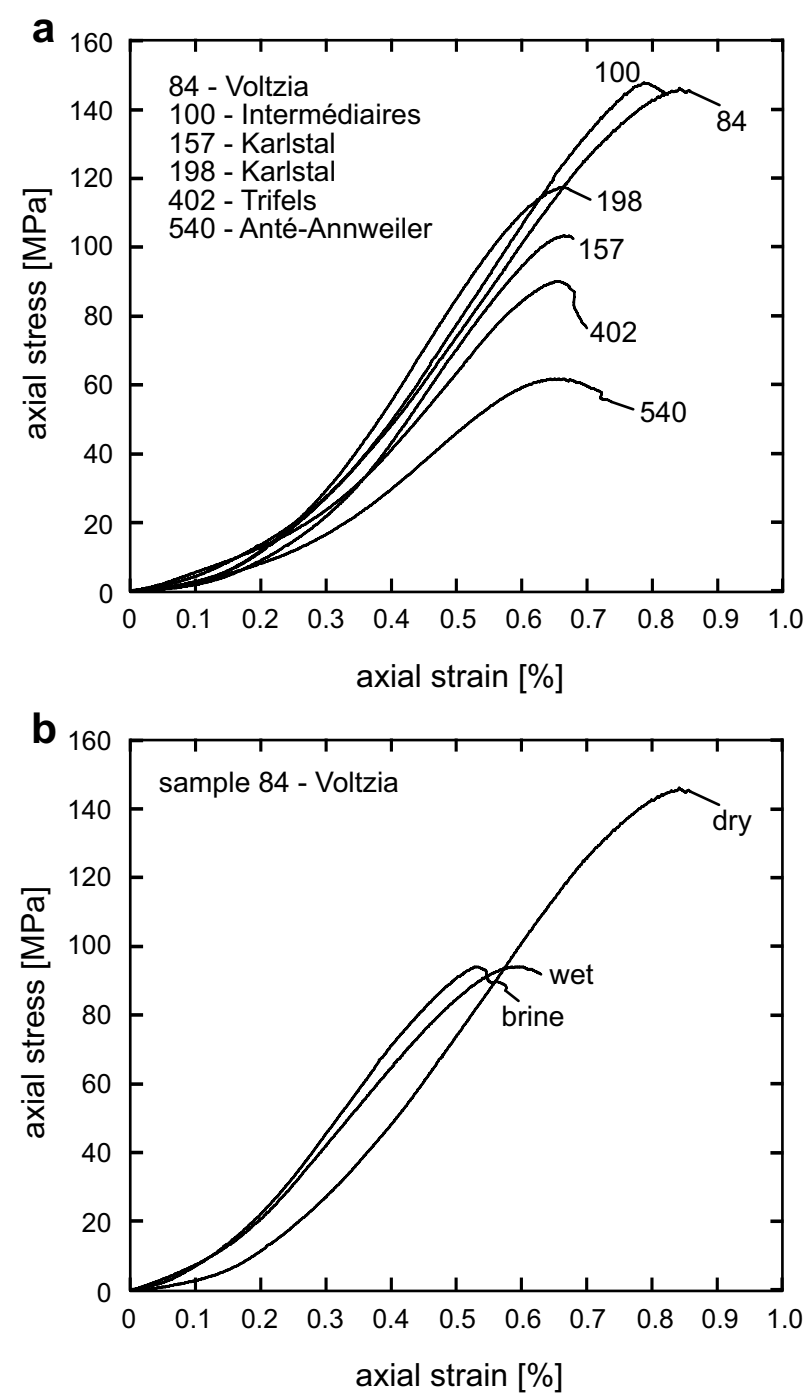

Fig. 5 a Representative dry uniaxial stress-strain curves the six sandstones sampled from exploration well EPS-1 at Soultz-sous-Forêts (France). The number next to each curve indicates the core box number. $\mathbf{b}$ Representative dry, water-saturated, and brine-saturated uniaxial stress-strain curves for samples taken from core box number 84

\section{Discussion}

Influence of water on the strength of sandstone

Our uniaxial compressive strength experiments show that the Buntsandstein sandstone is weaker in the presence of water (Figs. 5, 6, and 7), in accordance with published studies on sandstones from the Buntsandstein (Heap et al. 2019) and most other clay-bearing sandstones (e.g., Bell 1978; Hawkins and McConnell 1992; Baud et al. 2000). Bentheim sandstone and Fontainebleau sandstone, however, sandstones composed of essentially $100 \mathrm{wt} \%$ quartz, were found to have very similar dry- and watersaturated strengths (e.g., Reviron et al. 2009). The study of Heap et al. (2019) compiled the available data for water-weakening in sandstone and showed that, although there is some scatter in the data, the ratio of wet-to-dry strength in sandstone decreased 
Table 4 Summary of the dry, water-saturated (wet), and brine-saturated (brine) uniaxial compressive strength experiments performed on the six sandstones sampled from exploration well EPS-1 at the Soultz-sous-Forêts geothermal site (France)

\begin{tabular}{|c|c|c|c|c|c|c|c|c|c|}
\hline $\begin{array}{l}\text { Box } \\
\text { number }\end{array}$ & $\begin{array}{l}\text { Depth } \\
\text { (m) }\end{array}$ & Unit & $\begin{array}{l}\text { Connected } \\
\text { porosity }\end{array}$ & $\begin{array}{l}\text { Dry } \\
\text { UCS } \\
\text { (MPa) }\end{array}$ & $\begin{array}{l}\text { Wet } \\
\text { UCS } \\
(\mathrm{MPa})\end{array}$ & $\begin{array}{l}\text { Brine } \\
\text { UCS } \\
\text { (MPa) }\end{array}$ & $\begin{array}{l}\text { Dry } \\
\text { elastic } \\
\text { modulus } \\
(\mathrm{GPa})\end{array}$ & $\begin{array}{l}\text { Wet } \\
\text { elastic } \\
\text { modulus } \\
(\mathrm{GPa})\end{array}$ & $\begin{array}{l}\text { Brine } \\
\text { elastic } \\
\text { modulus } \\
(\mathrm{GPa})\end{array}$ \\
\hline 84 & 1008 & Voltzia & 0.108 & - & 89.8 & - & - & 22.5 & - \\
\hline 84 & 1008 & Voltzia & 0.111 & - & 94.2 & - & - & 22.7 & - \\
\hline 84 & 1008 & Voltzia & 0.108 & - & 85.9 & - & - & 19.7 & - \\
\hline 84 & 1008 & Voltzia & 0.107 & 152.9 & - & - & 30.0 & - & - \\
\hline 84 & 1008 & Voltzia & 0.114 & 146.0 & - & - & 26.5 & - & - \\
\hline 84 & 1008 & Voltzia & 0.111 & 139.7 & - & - & 23.7 & - & - \\
\hline 84 & 1008 & Voltzia & 0.109 & - & - & 94.6 & - & - & 24.3 \\
\hline 84 & 1008 & Voltzia & 0.113 & - & - & 94.1 & - & - & 25.3 \\
\hline 84 & 1008 & Voltzia & 0.114 & - & - & 94.3 & - & - & 24.3 \\
\hline 100 & 1022 & $\begin{array}{r}\text { Intermé- } \\
\text { diaires }\end{array}$ & 0.074 & - & 123.4 & - & - & 29.5 & - \\
\hline 100 & 1022 & $\begin{array}{l}\text { Intermé- } \\
\text { diaires }\end{array}$ & 0.074 & - & 124.5 & - & - & 30.7 & - \\
\hline 100 & 1022 & $\begin{array}{r}\text { Intermé- } \\
\text { diaires }\end{array}$ & 0.076 & - & 92.3 & - & - & 22.1 & - \\
\hline 100 & 1022 & $\begin{array}{r}\text { Intermé- } \\
\text { diaires }\end{array}$ & 0.077 & 132.1 & - & - & 26.6 & - & - \\
\hline 100 & 1022 & $\begin{array}{r}\text { Intermé- } \\
\text { diaires }\end{array}$ & 0.072 & 147.6 & - & - & 28.5 & - & - \\
\hline 100 & 1022 & $\begin{array}{l}\text { Intermé- } \\
\text { diaires }\end{array}$ & 0.073 & 148.5 & - & - & 28.4 & - & - \\
\hline 100 & 1022 & $\begin{array}{l}\text { Intermé- } \\
\text { diaires }\end{array}$ & 0.079 & - & - & 100.4 & - & - & 30.1 \\
\hline 100 & 1022 & $\begin{array}{r}\text { Intermé- } \\
\text { diaires }\end{array}$ & 0.080 & - & 86.8 & - & - & 19.5 & - \\
\hline 100 & 1022 & $\begin{array}{r}\text { Intermé- } \\
\text { diaires }\end{array}$ & 0.077 & - & - & 86.1 & - & - & 21.9 \\
\hline 100 & 1022 & $\begin{array}{l}\text { Intermé- } \\
\text { diaires }\end{array}$ & 0.075 & - & - & 96.1 & - & - & 23.0 \\
\hline 157 & 1069 & Karlstal & 0.127 & - & 74.7 & - & - & 25.4 & - \\
\hline 157 & 1069 & Karlstal & 0.125 & - & 71.8 & - & - & 25.9 & - \\
\hline 157 & 1069 & Karlstal & 0.133 & - & 68.2 & - & - & 21.5 & - \\
\hline 157 & 1069 & Karlstal & 0.126 & - & 85.7 & - & - & 25.6 & - \\
\hline 157 & 1069 & Karlstal & 0.128 & 102.2 & - & - & 29.5 & - & - \\
\hline 157 & 1069 & Karlstal & 0.130 & 103.3 & - & - & 27.9 & - & - \\
\hline 157 & 1069 & Karlstal & 0.130 & 103.7 & - & - & 31.0 & - & - \\
\hline 157 & 1069 & Karlstal & 0.128 & - & - & 90.8 & - & - & 28.0 \\
\hline 157 & 1069 & Karlstal & 0.127 & - & - & 90.4 & - & - & 28.5 \\
\hline 157 & 1069 & Karlstal & 0.130 & - & - & 89.2 & - & - & 28.6 \\
\hline 198 & 1107 & Karlstal & 0.098 & - & 83.8 & - & - & 26.5 & - \\
\hline 198 & 1107 & Karlstal & 0.092 & - & 82.9 & - & - & 24.5 & - \\
\hline 198 & 1107 & Karlstal & 0.093 & - & 93.9 & - & - & 27.5 & - \\
\hline 198 & 1107 & Karlstal & 0.099 & 107.9 & - & - & 31.6 & - & - \\
\hline 198 & 1107 & Karlstal & 0.095 & 124.3 & - & - & 31.1 & - & - \\
\hline 198 & 1107 & Karlstal & 0.091 & 117.4 & - & - & 29.9 & - & - \\
\hline 198 & 1107 & Karlstal & 0.091 & - & - & 98.0 & - & - & 29.2 \\
\hline 198 & 1107 & Karlstal & 0.102 & - & 94.6 & - & - & 31.4 & - \\
\hline 198 & 1107 & Karlstal & 0.090 & - & - & 93.7 & - & - & 27.3 \\
\hline
\end{tabular}


Table 4 (continued)

\begin{tabular}{|c|c|c|c|c|c|c|c|c|c|}
\hline $\begin{array}{l}\text { Box } \\
\text { number }\end{array}$ & $\begin{array}{l}\text { Depth } \\
\text { (m) }\end{array}$ & Unit & $\begin{array}{l}\text { Connected } \\
\text { porosity }\end{array}$ & $\begin{array}{l}\text { Dry } \\
\text { UCS } \\
\text { (MPa) }\end{array}$ & $\begin{array}{l}\text { Wet } \\
\text { UCS } \\
(\mathrm{MPa})\end{array}$ & $\begin{array}{l}\text { Brine } \\
\text { UCS } \\
\text { (MPa) }\end{array}$ & $\begin{array}{l}\text { Dry } \\
\text { elastic } \\
\text { modulus } \\
(\mathrm{GPa})\end{array}$ & $\begin{array}{l}\text { Wet } \\
\text { elastic } \\
\text { modulus } \\
(\mathrm{GPa})\end{array}$ & $\begin{array}{l}\text { Brine } \\
\text { elastic } \\
\text { modulus } \\
(\mathrm{GPa})\end{array}$ \\
\hline 198 & 1107 & Karlstal & 0.091 & - & - & 93.6 & - & - & 27.3 \\
\hline 402 & 1290 & Trifels & 0.138 & - & 64.8 & - & - & 19.2 & - \\
\hline 402 & 1290 & Trifels & 0.139 & - & 61.8 & - & - & 18.6 & - \\
\hline 402 & 1290 & Trifels & 0.146 & - & 61.9 & - & - & 19.4 & - \\
\hline 402 & 1290 & Trifels & 0.146 & - & 53.4 & - & - & 14.9 & - \\
\hline 402 & 1290 & Trifels & 0.147 & 95.8 & - & - & 20.7 & - & - \\
\hline 402 & 1290 & Trifels & 0.145 & 90.1 & - & - & 22.2 & - & - \\
\hline 402 & 1290 & Trifels & 0.149 & 84.1 & - & - & 19.9 & - & - \\
\hline 402 & 1290 & Trifels & 0.142 & - & - & 63.8 & - & - & 19.0 \\
\hline 402 & 1290 & Trifels & 0.138 & - & - & 63.2 & - & - & 19.1 \\
\hline 402 & 1290 & Trifels & 0.146 & - & - & 62.1 & - & - & 20.4 \\
\hline 402 & 1290 & Trifels & 0.148 & - & - & 62.8 & - & - & 19.6 \\
\hline 540 & 1414 & $\begin{array}{l}\text { Anté- } \\
\text { Ann- } \\
\text { weiler }\end{array}$ & 0.096 & - & 42.0 & - & - & 13.9 & - \\
\hline 540 & 1414 & $\begin{array}{l}\text { Anté- } \\
\text { Ann- } \\
\text { weiler }\end{array}$ & 0.102 & - & 42.2 & - & - & 14.3 & - \\
\hline 540 & 1414 & $\begin{array}{l}\text { Anté- } \\
\text { Ann- } \\
\text { weiler }\end{array}$ & 0.099 & - & 38.6 & - & - & 12.8 & - \\
\hline 540 & 1414 & $\begin{array}{l}\text { Anté- } \\
\text { Ann- } \\
\text { weiler }\end{array}$ & 0.098 & 72.1 & - & - & 18.0 & - & - \\
\hline 540 & 1414 & $\begin{array}{l}\text { Anté- } \\
\text { Ann- } \\
\text { weiler }\end{array}$ & 0.106 & 59.4 & - & - & 14.9 & - & - \\
\hline 540 & 1414 & $\begin{array}{l}\text { Anté- } \\
\text { Ann- } \\
\text { weiler }\end{array}$ & 0.102 & 61.8 & - & - & 16.2 & - & - \\
\hline 540 & 1414 & $\begin{array}{l}\text { Anté- } \\
\text { Ann- } \\
\text { weiler }\end{array}$ & 0.103 & - & - & 38.1 & - & - & 12.8 \\
\hline 540 & 1414 & $\begin{array}{l}\text { Anté- } \\
\text { Ann- } \\
\text { weiler }\end{array}$ & 0.094 & - & - & 41.0 & - & - & 12.7 \\
\hline 540 & 1414 & $\begin{array}{l}\text { Anté- } \\
\text { Ann- } \\
\text { weiler }\end{array}$ & 0.099 & - & - & 39.2 & - & - & 14.2 \\
\hline
\end{tabular}

as clay content increased. In other words, the higher the clay content, the greater the observed water-weakening. Water-weakening in sandstone was considered by these authors to be the result of a reduction in specific surface-free energy in the presence of water (see also Rehbinder et al. 1948; Baud et al. 2000, 2015). Heap et al. (2019) suggested that, due to the ability of clays to adsorb water, a higher clay content ensured that more water was adsorbed on the surface of growing microcracks, resulting in a lower ratio of wet-to-dry strength. Although we do not observe a clear trend of waterweakening with clay content in this study (Fig. 7b), we similarly conclude that the measured water-weakening is a result of a reduction of specific surface-free energy. 

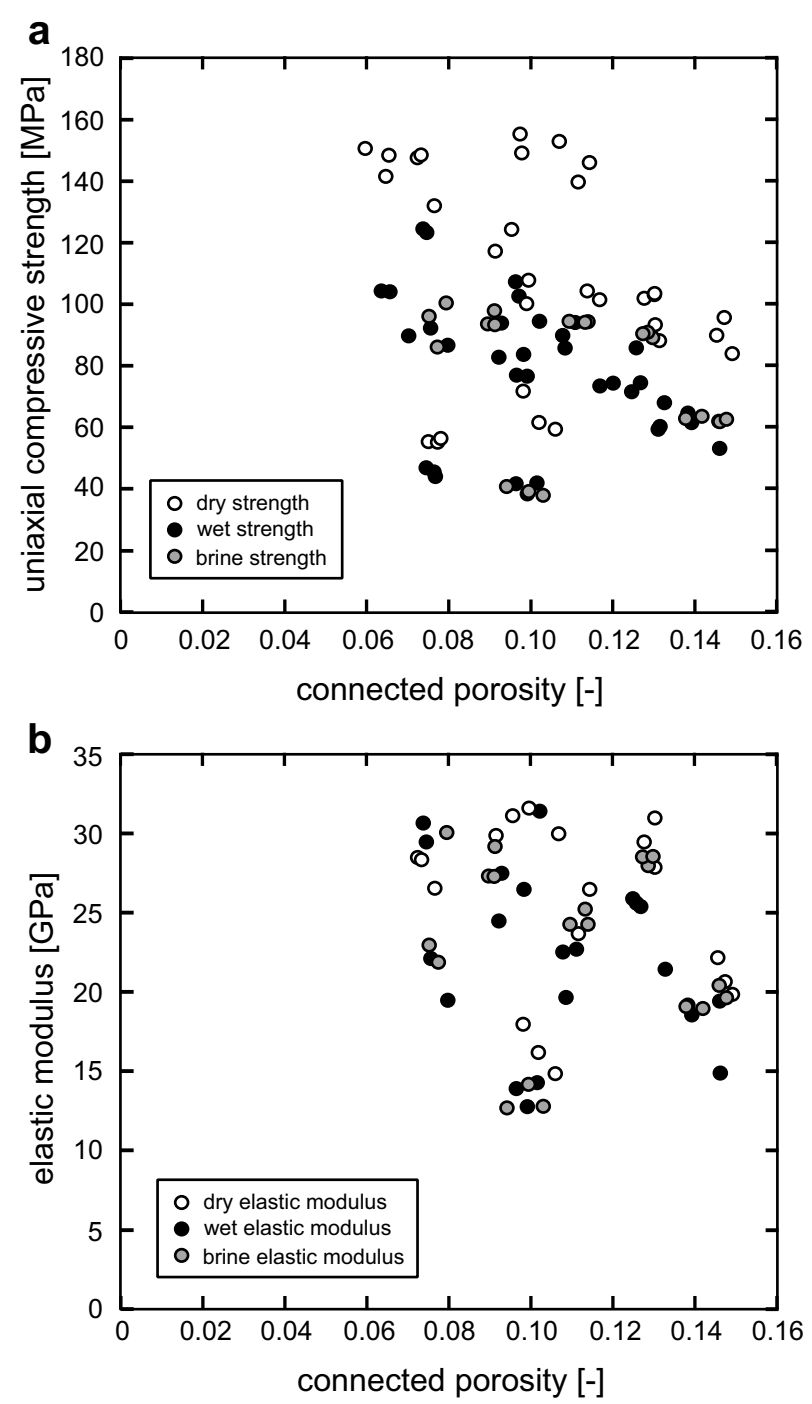

Fig. 6 a Dry (white circles), water-saturated (black circles), and brine-saturated (grey circles) uniaxial compressive strength for the six sandstones sampled from exploration well EPS-1 at Soultz-sous-Forêts (France) as a function of connected porosity. b Dry (white circles), water-saturated (black circles), and brine-saturated (grey circles) static elastic modulus for the six sandstones sampled from exploration well EPS-1 at Soultz-sous-Forêts as a function of connected porosity

We also note that the dry- and water-saturated strengths measured here (Table 4) are similar to those measured by Heap et al. (2019) at a lower strain rate of $1.0 \times 10^{-6} \mathrm{~s}^{-1}$, highlighting that strain rate does not significantly influence of the strength of these sandstones over this narrow range of strain rate $\left(10^{-6}-10^{-5} \mathrm{~s}^{-1}\right)$. To better understand the role of strain rate on the strength of porous Buntsandstein sandstone, we performed six additional experiments on water-saturated samples of Rothbach sandstone (a sandstone from the Karlstal unit sourced from a local quarry that contains a porosity of $\sim 0.2$; Heap et al. 2017). These experiments were performed at strain rates between $10^{-4} \mathrm{~s}^{-1}$ (lasting $1.5 \mathrm{~min}$ ) and $10^{-9} \mathrm{~s}^{-1}$ (lasting $\sim 115$ days) (Fig. 9; Table 7). These experiments show that uniaxial compressive strength is slightly reduced at 
Table 5 Summary of the average dry, water-saturated (wet), and brine-saturated (brine) uniaxial compressive strength experiments performed on the six sandstones sampled from exploration well EPS-1 at the Soultz-sous-Forêts geothermal site (France)

\begin{tabular}{lllllll}
\hline $\begin{array}{l}\text { Sample } \\
\text { box } \\
\text { number }\end{array}$ & $\begin{array}{l}\text { Average } \\
\text { dry UCS } \\
\text { (MPa) }\end{array}$ & $\begin{array}{l}\text { Average } \\
\text { wet UCS } \\
\text { (MPa) }\end{array}$ & $\begin{array}{l}\text { Average } \\
\text { brine UCS } \\
\text { (MPa) }\end{array}$ & $\begin{array}{l}\text { Average } \\
\text { dry elastic } \\
\text { modulus (GPa) }\end{array}$ & $\begin{array}{l}\text { Average } \\
\text { wet elastic } \\
\text { modulus (GPa) }\end{array}$ & $\begin{array}{l}\text { Average brine } \\
\text { elastic modulus } \\
\text { (GPa) }\end{array}$ \\
\hline 84 & 146.2 & 90.0 & 94.3 & 26.9 & 21.6 & 24.6 \\
100 & 142.7 & 106.8 & 94.2 & 27.8 & 25.5 & 25.0 \\
157 & 103.1 & 75.1 & 90.1 & 29.5 & 24.6 & 28.4 \\
198 & 116.5 & 88.8 & 95.1 & 30.9 & 27.5 & 27.9 \\
402 & 90.0 & 60.5 & 63.0 & 20.9 & 18.0 & 19.5 \\
540 & 64.4 & 40.9 & 39.4 & 16.4 & 13.7 & 13.2 \\
\hline
\end{tabular}

UCS uniaxial compressive strength

strain rates $<10^{-8} \mathrm{~s}^{-1}$ (Fig. 9; Table 7), although the strength differences measured are close to the range expected from the natural variability of porous sandstones. These data are in line with other data that suggest a weak strain rate dependence of strength for porous sandstone in the brittle field (Paterson and Wong 2005 and references therein).

\section{Influence of hydrothermal brine on the strength of sandstone}

Based on the measured TDS (Table 3), the salinity of the hydrothermal brine from production well GPK-2 (Soultz-sous-Forêts) is 10\%. Experimental studies have reported that the uniaxial compressive strength of sandstone decreases as salinity is increased from 0 to $10 \% \mathrm{NaCl}$, and that strength increases as salinity is increased above $10 \% \mathrm{NaCl}$ (Shukla et al. 2013; Rathnaweera et al. 2014). The ratios of water-saturated-to-brinesaturated strengths reported in Shukla et al. (2013) and Rathnaweera et al. (2014), for a brine concentration similar to the brine used herein $(10 \% \mathrm{NaCl})$, are $1.05,1.22$, and 1.10 for Melbourne sandstone (S-type), Melbourne sandstone (M-type), and Gosford sandstone, respectively (Table 6). Since these ratios are above unity, these studies found, as mentioned above, that the UCS of sandstone is lowered when saturated with $10 \%$ $\mathrm{NaCl}$ brine (relative to the wet strength). Based on these studies, and the salinity of the brine from production well GPK-2, the brine-saturated strengths of the Buntsandstein sandstones measured herein should be lower than their water-saturated strengths. The lower $\mathrm{pH}$ of the hydrothermal brine of 5.5 (Table 3) should also result in a reduction in strength relative to the water-saturated case $(\mathrm{pH}=7)$ (Singh et al. 1999; Wang et al. 2015). We further note that reductions in specific surface-free energy should be higher as the concentration of hydrogen ions, hydroxide ions, and electrolytes increases (Parks 1984). However, the average brine-saturated strengths of four of the six sandstones tested are slightly higher than their average water-saturated strengths (Table 5). We do not, however, interpret these small increases in strength (ratios of water-saturatedto-brine-saturated strengths of $0.95,0.83,0.93$, and 0.96 for samples $84,100,402$, and 540 , respectively; Table 6), or the small decrease in strength observed in two of the six sandstones (ratios of water-saturated-to-brine-saturated strengths of 1.04 and 1.13 for samples 157 and 198, respectively; Table 6), as a consequence of the presence of hydrothermal brine. We consider this variation in strength as a result of the natural variability 

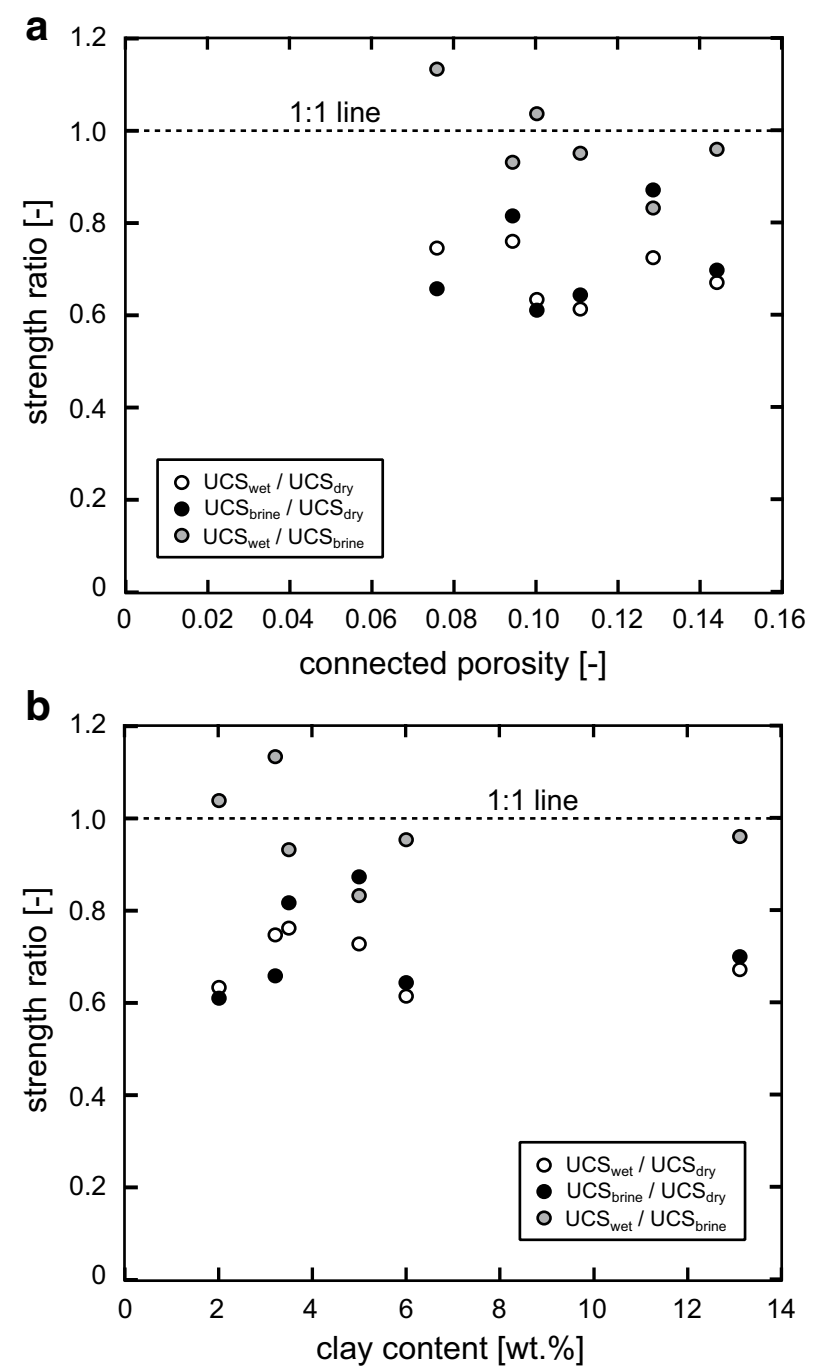

Fig. 7 a Ratios of water-saturated-to-dry uniaxial compressive strength, brine-saturated-to-dry uniaxial compressive strength, and water-saturated-to-brine-saturated uniaxial compressive strength for the six sandstones sampled from exploration well EPS-1 at Soultz-sous-Forêts (France) as a function of connected porosity. b Ratios of water-saturated-to-dry uniaxial compressive strength, brine-saturated-to-dry uniaxial compressive strength, and water-saturated-to-brine-saturated uniaxial compressive strength for the six sandstones sampled from exploration well EPS-1 at Soultz-sous-Forêts as a function of clay content (clay content is the wt\% of muscovite/illite-smectite; Table 1)

(i.e., slight variations in porosity, average grain size, and average pore size, amongst others) between samples prepared from the same section of core. For example, the variation in dry strength for the three 84 samples was on the order of $10 \%$ (Table 4 ). We also highlight that the strength of the brine-saturated samples relative to the water-saturated samples did not vary systematically with connected porosity, grain size, or clay content (Table 4; Figs. 6, 7, and 8). Natural variability could also explain the difference between the water-saturated and brine-saturated strengths reported in Shukla et al. (2013) (Table 6). For example, the dry UCS of Melbourne sandstone (M-type) varied between 160 and $190 \mathrm{MPa}$ (Shukla et al. 2013). The Gosford sandstone used in Rathnaweera et al. (2014), however, was very reproducible (values of dry UCS for three samples were 38.95, 
Table 6 Summary of the average ratios of water-saturated-to-dry, brine-saturated-todry, and water-saturated-to-brine-saturated strengths and static elastic moduli for the six sandstones sampled from exploration well EPS-1 at the Soultz-sous-Forêts geothermal site (France)

\begin{tabular}{|c|c|c|c|c|c|c|}
\hline Sample box number & $\begin{array}{l}\text { UCS } \\
\text { wet/UCS } \\
\text { dry }\end{array}$ & $\begin{array}{l}\text { UCS } \\
\text { brine/ } \\
\text { UCS dry }\end{array}$ & $\begin{array}{l}\text { UCS wet/ } \\
\text { UCS } \\
\text { brine }\end{array}$ & E wet/E dry & E brine/E dry & E wet/E brine \\
\hline 84 & 0.62 & 0.65 & 0.95 & 0.81 & 0.92 & 0.88 \\
\hline 100 & 0.73 & 0.87 & 0.83 & 0.83 & 0.96 & 0.87 \\
\hline 157 & 0.64 & 0.61 & 1.04 & 0.84 & 0.81 & 1.03 \\
\hline 198 & 0.75 & 0.66 & 1.13 & 0.91 & 0.90 & 1.02 \\
\hline 402 & 0.76 & 0.82 & 0.93 & 0.89 & 0.90 & 0.98 \\
\hline 540 & 0.67 & 0.70 & 0.96 & 0.86 & 0.93 & 0.92 \\
\hline $\begin{array}{l}\text { Melbourne sandstone (S-type) } \\
\text { (Shukla et al. 2013) }\end{array}$ & 0.39 & 0.37 & 1.05 & - & - & - \\
\hline $\begin{array}{l}\text { Melbourne sandstone (M-type) } \\
\text { (Shukla et al. 2013) }\end{array}$ & 0.76 & 0.63 & 1.22 & - & - & - \\
\hline $\begin{array}{l}\text { Gosford sandstone } \\
\text { (Rathnaweera et al. 2014) }\end{array}$ & 0.64 & 0.58 & 1.10 & - & - & - \\
\hline
\end{tabular}

The UCS of the brine-saturated samples taken from Shukla et al. (2013) and Rathnaweera et al. (2014) correspond to the salt concentration closest to that tested herein ( $\mathrm{NaCl} 10 \%)$

UCS uniaxial compressive strength, $E$ static elastic modulus

39.96 , and $39.63 \mathrm{MPa}$, respectively), adding veracity to the measured ratio of watersaturated-to-brine-saturated strength of 1.10 (Table 6). It is our opinion that the influence of natural variability on the strength of the Buntsandstein sandstones measured herein is greater than the combined influence of the salinity $(\sim 10 \%)$ and $\mathrm{pH}(5.5)$ of the hydrothermal brine at Soultz-sous-Forêts. However, we do not rule out that hydrothermal brines with higher salinities and lower values of $\mathrm{pH}$ could influence the mechanical behaviour of sandstones in a geothermal context. As with the water-saturated tests, we conclude here that the observed reduction in the short-term strength and elastic modulus in the presence of brine, relative to the dry state, is the result of a reduction of specific surface-free energy.

\section{Implications for geothermal energy exploitation}

Our study shows that the strength and elastic modulus of the Buntsandstein is not greatly influenced by hydrothermal brine, relative to the water-saturated (deionised water) state (Figs. 5, 6, 7, and 8). This result, therefore, adds confidence to the upscaled rock-mass estimates of strength and elastic modulus for the water-saturated Bundsandstein sedimentary sequence provided in Heap et al. (2019). Recent and future geothermal exploitation in the Upper Rhine Graben has and will continue to target the interface between the fractured granitic basement and the overlying sedimentary rocks. Given the lateral extent of the Buntsandstein in this region (e.g., Aichholzer et al. 2016; Vidal and Genter 2018), the estimates of rock-mass strength and elastic modulus for the Bundsandstein provided in Heap et al. (2019) could be used to assist prospection, stimulation, and optimisation strategies at geothermal sites within the Upper Rhine Graben.

Although we provide strength measurements for Bundsandstein sandstone samples saturated with the in situ hydrothermal brine, our experiments were performed at room temperature. The temperature of the Buntsandstein sandstones at 

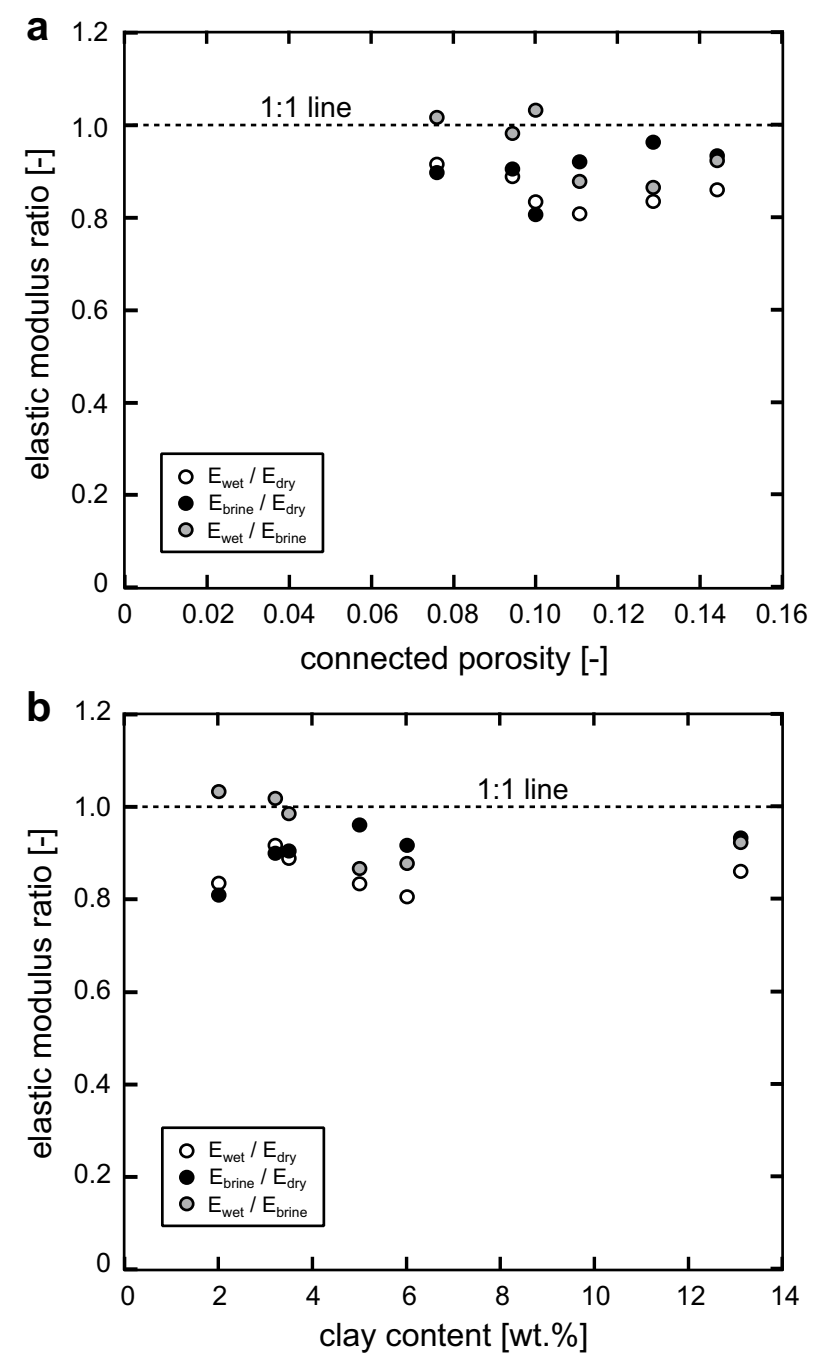

Fig. 8 a Ratios of water-saturated-to-dry elastic modulus, brine-saturated-to-dry elastic modulus, and wat er-saturated-to-brine-saturated elastic modulus for the six sandstones sampled from exploration well EPS-1 at Soultz-sous-Forêts (France) as a function of connected porosity. $\mathbf{b}$ Ratios of water-saturated-to-dry elastic modulus, brine-saturated-to-dry elastic modulus, and water-saturated-to-brine-saturated elastic modulus for the six sandstones sampled from exploration well EPS-1 at Soultz-sous-Forêts as a function of clay content (clay content is the wt\% of muscovite/illite-smectite; Table 1)

the Soultz-sous-Forêts geothermal site is between 120 and $140{ }^{\circ} \mathrm{C}$ (e.g., Genter et al. 2010). Experimental studies that investigate the influence of temperature on the strength and elastic modulus of sandstone are rare. Ranjith et al. (2012), for example, found that, as the testing temperature was increased from 25 to $200{ }^{\circ} \mathrm{C}$, the elastic modulus and uniaxial compressive strength of Hawkesbury sandstone (containing $20 \%$ clay) increased from 2.8 to $3.3 \mathrm{GPa}$ and from 36.5 to $42.5 \mathrm{MPa}$, respectively. An increase in elastic modulus and uniaxial compressive strength as temperature was increased from 25 to $150{ }^{\circ} \mathrm{C}$ was also observed by Rao et al. (2007). However, an increase in temperature from room temperature to $75^{\circ} \mathrm{C}$ was observed to reduce the strength of three sandstones under triaxial conditions, interpreted as the result of the 


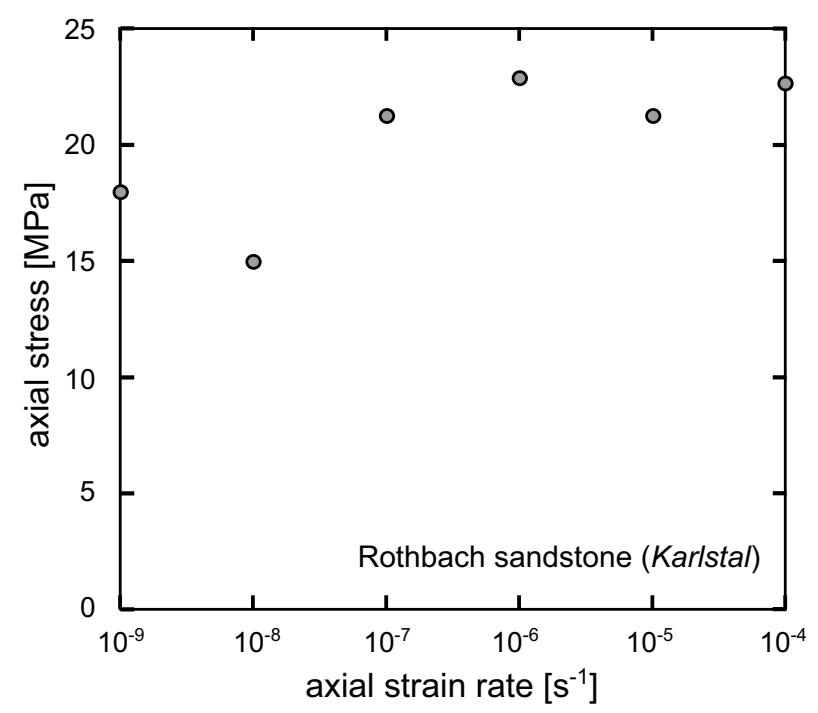

Fig. 9 Uniaxial compressive strength of water-saturated Rothbach sandstone as a function of axial strain rate (data given in Table 7)

Table 7 Summary of the uniaxial compressive strength experiments performed on Rothbach sandstone at different strain rates

\begin{tabular}{ll}
\hline Axial strain rate $\left(\mathbf{s}^{\mathbf{- 1}}\right)$ & $\begin{array}{l}\text { Uniaxial } \\
\text { compressive } \\
\text { strength }(\mathbf{M P a})\end{array}$ \\
\hline $1 \times 10^{-4}$ & 22.7 \\
$1 \times 10^{-5}$ & 21.3 \\
$1 \times 10^{-6}$ & 22.9 \\
$1 \times 10^{-7}$ & 21.3 \\
$1 \times 10^{-8}$ & 15.0 \\
$1 \times 10^{-9}$ & 18.0 \\
\hline
\end{tabular}

enhancement of stress corrosion cracking at high temperature (Heap et al. 2009b). It is clear that experiments under the in situ temperature conditions are now required to further fine-tune upscaled rock-mass estimates of strength and elastic modulus for the Bundsandstein sedimentary sequence.

\section{Conclusions}

A recent study by Heap et al. (2019) provided upscaled rock-mass estimates of strength and elastic modulus for the Bundsandstein sedimentary sequence using experiments performed on water-saturated samples. However, the rocks in situ are saturated with hydrothermal brines. It is reasonable to assume that the high salinity (TDS of $97 \mathrm{~g} / \mathrm{l}$ ) (e.g., Shukla et al. 2013; Rathnaweera et al. 2014) and low pH (5.5) (e.g., Parks 1984; Singh et al. 1999; Wang et al. 2015) of these brines could influence the strength and elastic modulus of these sandstones. To help fine-tune estimates of rock-mass strength and elastic modulus for the Bundsandstein, we performed 59 uniaxial compression tests on oven-dry, water-saturated (deionised water), and brine-saturated samples of 
Bundsandstein sampled from exploration well EPS-1 at the Soultz-sous-Forêts geothermal site. For the brine-saturated samples, we used hydrothermal brine sourced from production well GPK-2 at Soultz-sous-Forêts. Although we measure reductions in strength and elastic modulus for the water- and brine-saturated samples relative to the oven-dry samples, there are no measurable differences between the strength and elastic modulus of samples saturated with water and brine. Changes to strength and elastic modulus in the presence of hydrothermal brines likely require brines with higher salinities and lower values of $\mathrm{pH}$ than those found within the Upper Rhine Graben. Although the results of this study add confidence to the estimates of rock-mass strength and elastic modulus for the Bundsandstein provided by Heap et al. (2019), we highlight that the in situ temperature $\left(120-140^{\circ} \mathrm{C}\right)$ may yet influence their mechanical behaviour and, therefore, offers an inviting avenue for future research.

\section{Authors' contributions}

MJH led the project and wrote the manuscript. MJH, ARLK, and PB chose and collected the samples from the MerkwillerPechelbronn core repository. MJH measured porosity, uniaxial compressive strength, and static elastic modulus. TR performed the experiments on Rothbach sandstone at different strain rates. All authors had a hand in the preparation of the manuscript and the interpretation of the data. All authors read and approved the final manuscript.

\section{Acknowledgements}

We wish to thank Vincent Maurer, Regis Hehn, and Albert Genter at ES Géothermie for providing the hydrothermal brine. Bertrand Renaudié helped with sample preparation. We thank Chrystel Dezayes for her enthusiastic support. The comments of two anonymous reviewers and the editor helped improve this manuscript.

\section{Competing interests}

The authors declare that they have no competing interests.

\section{Availability of data and materials}

The data collected for this study are available in Tables 1, 2, 3, 4, 5, 6.

\section{Funding}

This study was funded by LABEX grant ANR-11-LABX-0050 G-EAU-THERMIE-PROFONDE (this research, therefore, benefited from state funding managed by the Agence National de la Recherche (ANR) as part of the "Investissements d'avenir" program) and ANR grant CANTARE (ANR-15-CE06-0014-01).

\section{Publisher's Note}

Springer Nature remains neutral with regard to jurisdictional claims in published maps and institutional affiliations.

Received: 22 October 2018 Accepted: 17 December 2018

Published online: 26 December 2018

\section{References}

Aichholzer C, Duringer P, Orciani S, Genter A. New stratigraphic interpretation of the Soultz-sous-Forêts 30-year-old geothermal wells calibrated on the recent one from Rittershoffen (Upper Rhine Graben, France). Geotherm Energy. 2016;4:13.

Aquilina L, Pauwels H, Genter A, Fouillac C. Water-rock interaction processes in the Triassic sandstone and the granitic basement of the Rhine Graben: geochemical investigation of a geothermal reservoir. Geochim Cosmochim Acta. 1997;61:4281-95.

Atkinson BK, Meredith PG. Stress corrosion cracking of quartz: a note on the influence of chemical environment. Tectono. 1981;77:T1-11.

Baillieux P, Schill E, Edel JB, Mauri G. Localization of temperature anomalies in the Upper Rhine Graben: insights from geophysics and neotectonic activity. Int Geol Rev. 2013;55:1744-62.

Baria R, Baumgärtner J, Gérard A, Jung R, Garnish J. European HDR research programme at Soultz-sous-Forêts (France) 1987-1996. Geothermics. 1999;28(4):655-69.

Bartier D, Ledésert B, Clauer N, Meunier A, Liewig N, Morvan G, Addad A. Hydrothermal alteration of the Soultz-sousForêts granite (Hot Fractured Rock geothermal exchanger) into a tosudite and illite assemblage. Eur J Mineral. 2008;20:131-42.

Baud P, Zhu W, Wong TF. Failure mode and weakening effect of water on sandstone. J Geophys Res. 2000;105(B7):16371-89.

Baud P, Klein E, Wong TF. Compaction localization in porous sandstones: spatial evolution of damage and acoustic emission activity. J Struct Geol. 2004;26:603-24. 
Baud P, Reuschlé T, Ji Y, Cheung CS, Wong TF. Mechanical compaction and strain localization in Bleurswiller sandstone. J Geophys Res. 2015;120:6501-22.

Baujard C, Genter A, Dalmais E, Maurer V, Hehn R, Rosillette R, Vidal J, Schmittbuhl J. Hydrothermal characterization of wells GRT-1 and GRT-2 in Rittershoffen, France: implications on the understanding of natural flow systems in the Rhine graben. Geothermics. 2017;65:255-68.

Bell FG. Petrographical factors relating to porosity and permeability in the Fell Sandstone. Q J Eng Geol Hydrogeol. 1978;11(2):113-26.

Bésuelle P, Baud P, Wong TF. Failure mode and spatial distribution of damage in Rothbach sandstone in the brittle-ductile transition. Pure Appl Geophys. 2003;160:851-68.

Buchmann TJ, Connolly PT. Contemporary kinematics of the Upper Rhine Graben: a 3D finite element approach. Glob Planet Change. 2007;58:287-309.

Dezayes C, Genter A, Valley B. Structure of the low permeable naturally fractured geothermal reservoir at Soultz. CR Geosci. 2010;342:517-30.

Feucht L, Logan JM. Effects of chemically active solutions on shearing behavior of a sandstone. Tectono. 1990;175:159-76.

Fortin J, Schubnel A, Guéguen Y. Elastic wave velocities and permeability evolution during compaction of Bleurswiller sandstone. Int J Rock Mech Min Sci. 2005;42:873-89.

Fritz B, Jacquot E, Jacquemont B, Baldeyrou-Bailly A, Rosener M, Vidal O. Geochemical modelling of fluid-rock interactions in the context of the Soultz-sous-Forêts geothermal system. CR Geosci. 2010;342:653-67.

Gérard A, Genter A, Kohl T. The deep EGS (Enhanced Geothermal System) project at Soultz-sous-Forêts (Alsace, France). Geothermics. 2006;35:473-83.

Genter A, Traineau H. Analysis of macroscopic fractures in granite in the HDR geothermal well EPS-1, Soultz-sous-Forêts, France. J Volcanol Geotherm Res. 1996;72:121-41.

Genter A, Castaing C, Dezayes C, Tenzer H, Traineau H, Villemin T. Comparative analysis of direct (core) and indirect (borehole imaging tools) collection of fracture data in the Hot Dry Rock Soultz reservoir (France). J Geophys Res. 1997:102:15419-31.

Genter A, Evans K, Cuenot N, Fritsch D, Sanjuan B. Contribution of the exploration of deep crystalline fractured reservoir of Soultz to the knowledge of enhanced geothermal systems (EGS). CR Geosci. 2010;342:502-16.

Glaas C, Genter A, Girard JF, Patrier P, Vidal J. How do the geological and geophysical signatures of permeable fractures in granitic basement evolve after long periods of natural circulation? Insights from the Rittershoffen geothermal wells (France). Geotherm Energy. 2018;6:14.

Griffiths L, Heap MJ, Wang F, Daval D, Gilg HA, Baud P, Schmittbuhl J, Genter A. Geothermal implications for fracture-filling hydrothermal precipitation. Geothermics. 2016;64:235-45.

Guillou-Frottier L, Carré C, Bourgine B, Bouchot V, Genter A. Structure of hydrothermal convection in the Upper Rhine Graben as inferred from corrected temperature data and basin-scale numerical models. JVolcanol Geotherm Res. 2013;256:29-49.

Haffen S, Géraud Y, Diraison M, Dezayes C. Determination of fluid-flow zones in a geothermal sandstone reservoir using thermal conductivity and temperature logs. Geothermics. 2013;46:32-41.

Hawkins AB, MCConnell BJ. Sensitivity of sandstone strength and deformability to changes in moisture content. Q J Eng Geol Hydrogeol. 1992;25:115-30.

Heap MJ, Baud P, Meredith PG, Bell AF, Main IG. Time-dependent brittle creep in Dale sandstone. J Geophys Res. 2009a;1 14(B7). https://doi.org/10.1029/2008JB006212.

Heap MJ, Baud P, Meredith PG. Influence of temperature on brittle creep in sandstones. Geophys Res Lett. 2009b;36(19). https://doi.org/10.1029/2009GL039373.

Heap MJ, Lavallée Y, Petrakova L, Baud P, Reuschlé T, Varley NR, Dingwell DB. Microstructural controls on the physical and mechanical properties of edifice-forming andesites at Volcán de Colima, Mexico. J Geophys Res. 2014;119(4):2925-63.

Heap MJ, Kushnir ARL, Gilg HA, Wadsworth FB, Reuschlé T, Baud P. Microstructural and petrophysical properties of the Permo-Triassic sandstones (Buntsandstein) from the Soultz-sous-Forêts geothermal site (France). Geotherm Energy. 2017:5(1):26.

Heap MJ, Villeneuve M, Kushnir ARL, Farquharson Jl, Baud P, Reuschlé T. Rock mass strength and elastic modulus of the Buntsandstein: an important lithostratigraphic unit for geothermal exploitation in the Upper Rhine Graben. Geothermics. 2019;77:236-56.

Hooijkaas GR, Genter A, Dezayes C. Deep-seated geology of the granite intrusions at the Soultz EGS site based on data from 5 km-deep boreholes. Geothermics. 2006;35:484-506.

Huang YH, Yang SQ, Hall MR, Zhang YC. The effects of $\mathrm{NaCl}$ concentration and confining pressure on mechanical and acoustic behaviors of brine-saturated sandstone. Energies. 2018;11(2):385.

Kappelmeyer O, Gérard A, Schloemer W, Ferrandes R, Rummel F, Benderitter Y. European HDR project at Soultz-sousForêts: general presentation. Geotherm Sci Tech. 1991;2(4):263-89.

Klein E, Baud P, Reuschlé T, Wong Tf. Mechanical behaviour and failure mode of Bentheim sandstone under triaxial compression. Phys Chem Earth. 2001;26(1-2):21-5.

Kushnir ARL, Heap MJ, Baud P. Assessing the role of fractures on the permeability of the Permo-Triassic sandstones at the Soultz-sous-Forêts (France) geothermal site. Geothermics. 2018a;74:181-9.

Kushnir ARL, Heap MJ, Baud P, Gilg HA, Reuschlé T, Lerouge C, Dezayes C, Duringer P. Characterizing the physical properties of rocks from the Paleozoic to Permo-Triassic transition in the Upper Rhine Graben. Geotherm Energy. 2018b;6:16.

Ledésert B, Dubois J, Genter A, Meunier A. Fractal analysis of fractures applied to Soultz-sous-Forêts hot dry rock geothermal program. JVolcanol Geotherm Res. 1993;57(1-2):1-17.

Ledésert B, Joffre J, Amblès A, Sardini P, Genter A, Meunier A. Organic matter in the Soultz HDR granitic thermal exchanger (France): natural tracer of fluid circulations between the basement and its sedimentary cover. J Volcanol Geotherm Res. 1996;70(3-4):235-53. 
Ledésert B, Berger G, Meunier A, Genter A, Bouchet A. Diagenetic-type reactions related to hydrothermal alteration in the Soultz-sous-Forêts granite, France. Eur J Mineral. 1999;11:731-41.

Ledésert B, Hebert R, Genter A, Bartier D, Clauer N, Grall C. Fractures, hydrothermal alterations and permeability in the Soultz Enhanced Geothermal System. CR Geosci. 2010;342:607-15.

Magnenet V, Fond C, Genter A, Schmittbuhl J. Two-dimensional THM modelling of the large scale natural hydrothermal circulation at Soultz-sous-Forêts. Geotherm Energy. 2014;2(1):17.

Menéndez B, Zhu W, Wong Tf. Micromechanics of brittle faulting and cataclastic flow in Berea sandstone. J Struct Geol. 1996;18(1):1-16.

Nara Y, Nakabayashi R, Maruyama M, Hiroyoshi N, Yoneda T, Kaneko K. Influences of electrolyte concentration on subcritical crack growth in sandstone in water. Eng Geol. 2014;179:41-9.

Parks GA. Surface and interfacial free energies of quartz. J Geophys Res. 1984;89(B6):3997-4008.

Paterson MS, Wong TF. Experimental rock deformation-the brittle field. Berlin: Springer Science \& Business Media; 2005.

Pribnow D, Schellschmidt R. Thermal tracking of upper crustal fluid flow in the Rhine Graben. Geophys Res Lett. 2000;27(13):1957-60.

Ranjith PG, Viete DR, Chen BJ, Perera MSA. Transformation plasticity and the effect of temperature on the mechanical behaviour of Hawkesbury sandstone at atmospheric pressure. Eng Geol. 2012;151:120-7.

Rathnaweera TD, Ranjith PG, Perera MSA. Salinity-dependent strength and stress-strain characteristics of reservoir rocks in deep saline aquifers: an experimental study. Fuel. 2014;122:1-11.

Rathnaweera TD, Ranjith PG, Perera MSA, Lashin A, Al Arifi N. Non-linear stress-strain behaviour of reservoir rock under brine saturation: an experimental study. Measurement. 2015;71:56-72

Rao QH, Wang Z, Xie HF, Xie Q. Experimental study of mechanical properties of sandstone at high temperature. J Cent South Univ Technol. 2007:14(1):478-83.

Rehbinder PA, Schreiner LA, Zhigach KF. Hardness reducers in drilling, translated from Russian. Melbourne: Counc Sci Ind Res; 1948.

Reviron N, ReuschléT, Bernard JD. The brittle deformation regime of water-saturated siliceous sandstones. Geophys J Int. 2009;178:1766-78.

Sanjuan B, Millot R, Dezayes C, Brach M. Main characteristics of the deep geothermal brine $(5 \mathrm{~km})$ at Soultz-sous-Forêts (France) determined using geochemical and tracer test data. CR Geosci. 2010;342:546-59.

Sanjuan B, Millot R, Innocent C, Dezayes C, Scheiber J, Brach M. Major geochemical characteristics of geothermal brines from the Upper Rhine Graben granitic basement with constraints on temperature and circulation. Chem Geol. 2016;428:27-47.

Sausse J. Hydromechanical properties and alteration of natural fracture surfaces in the Soultz granite (Bas-Rhin, France). Tectono. 2002;348:169-85.

Sausse J, Fourar M, Genter A. Permeability and alteration within the Soultz granite inferred from geophysical and flow log analysis. Geothermics. 2006;35(5-6):544-60.

Scheiber J, Nitschke F, Seibt A, Genter A. Geochemical and mineralogical monitoring of the geothermal power plant in Soultz-sous-Forêts (France). In: Proceedings of the 37th workshop on geothermal reservoir engineering. 2012. p. 1033-1042.

Shukla R, Ranjith PG, Choi SK, Haque A, Yellishetty M, Hong L. Mechanical behaviour of reservoir rock under brine saturation. Rock Mech Rock Eng. 2013;46:83-93.

Singh TN, Singh SK, Mishra A, Singh PK, Singh VK. Effect of acidic water on physico-mechanical behaviour of rock. Indian J Eng Mater Sci. 1999;6:66-72.

Vidal J, Genter A, Schmittbuhl J. How do permeable fractures in the Triassic sediments of Northern Alsace characterize the top of hydrothermal convective cells? Evidence from Soultz geothermal boreholes (France). Geotherm Energy. 2015;3:8.

Vidal J, Genter A, Schmittbuhl J. Pre-and post-stimulation characterization of geothermal well GRT-1, Rittershoffen, France: insights from acoustic image logs of hard fractured rock. Geophys J Int. 2016;206:845-60.

Vidal J, Genter A. Overview of naturally permeable fractured reservoirs in the central and southern Upper Rhine Graben: insights from geothermal wells. Geothermics. 2018;74:57-73.

Villeneuve M, Heap MJ, Kushnir ARL, Qin T, Baud P, Zhou G, Xu T. Estimating in situ rock mass strength and elastic modulus of granite from the Soultz-sous-Forêts geothermal reservoir (France). Geotherm Energy. 2018;6:11.

Wong TF, David C, Zhu W. The transition from brittle faulting to cataclastic flow in porous sandstones: mechanical deformation. J Geophys Res. 1997;102(B2):3009-25.

Wang W, Liu TG, Shao JF. Effects of acid solution on the mechanical behavior of sandstone. J Mater Civ Eng. 2015:28(1):04015089. 